\title{
PENUNDAAN PEMERIKSAAN DIFFERENTIAL COUNT TERHADAP GAMBARAN SCATTERGRAM HEMATOLOGY ANALYZER CELL-DYN RUBY
}

\author{
Delay On Differential Count Examination On Hematology Analyzer Cell-Dyn Ruby \\ Scattergram Images \\ ${ }^{1}$ Gilang Nugraha, ${ }^{2}$ Nur Anita Ningsih \\ ${ }^{1,2}$ D-IV Analis Kesehatan, Fakultas Kesehatan, Universitas Nahdlatul Ulama Surabaya
}

Koresponden: gilang@unusa.ac.id/+62 2233441232

\begin{abstract}
Over the past few decades, diff count examinations have been performed using a hematology analyzer. It has been reported that delay in examination can change the morphology of leukocytes in peripheral blood smears. Cell-Dyn Ruby is a 5-part differential hematology analyzer with multiangle polarized scatter separation (MAPSS) technology that forms the WBC Differential scattergram and NEU-EOS scattergram. The purpose of this study was to obtain an overview of the Cell-Dyn Ruby scattergram diff count on the delayed examination material. The study used an Experimental Laboratory design, the examination used a Cell-Dyn Ruby hematology analyzer. O hours examination as a control, 6, 12 and 24 hours examination as treatment. A total of 30 respondents participated in this study and obtained a scattergram image after the delay in the form of an increase in the number of dots in black and pink, as well as a widening of the distribution of orange dots. Based on statistical tests, there were significant differences in the results of the examination $(P<0.01)$ in all parameters of the leukocyte examination consisting of white blood cells (WBC), segmented neutrophils (SEG), band neutrophils (BAND), immature granulocytes (IG), monocytes (MONO), eosinophils (EO), basophils (BASO) and lymphocytes (LYM). Our results show that the examination delay can be detected by the Cell-Dyn Ruby scattergram especially the WBC Differential channel after a delay of 12 hours, and is noticeable after a delay of 24 hours. The suggestion of this research is the use of a scattergram for verification of the feasibility of examination materials and the need for further research to validate with blood smears and comparisons with other tools that have different technologies.
\end{abstract}

Keywords : delay, diff count, scattergram, Cell-Dyn Ruby

\begin{abstract}
ABSTRAK
Dilaporkan bahwa penundaan pemeriksaan dapat mengubah morfologi leukosit pada sediaan apusan darah tepi. Cell-Dyn Ruby merupakan salah satu hematology analyzer 5part differential dengan teknologi multiangle polarized scatter separation (MAPSS) yang membentuk scattergram WBC Differential dan scattergram NEU-EOS. Tujuan penelitian ini untuk mendapatkan gambaran scattergram diff count Cell-Dyn Ruby pada bahan pemeriksaan yang ditunda. Penelitian menggunakan desain Experimental Laboratory, pemeriksaan menggunakan hematology analyzer Cell-Dyn Ruby. Pemeriksaan 0 jam sebagai kontrol, pemeriksaan 6, 12 dan 24 jam sebagai perlakuan. Sebanyak 30 responden berpartisipasi dalam penelitian ini, gambaran scattergram setelah penundaan berupa
\end{abstract}


peningkatan jumlah titik pada warna hitam dan merah muda, serta adanya pelebaran distribusi titik warna oranye. Berdasarkan uji statistik, terdapat perbedaan hasil pemeriksaan secara signifikan $(\mathrm{P}<0,01)$ pada seluruh parameter pemeriksaan leukosit yang terdiri dari white blood cell (WBC), neutrofil segmen (SEG), neutrofil batang (BAND), immature granulocytes (IG), monosit (MONO), eosinofil (EO), basofil (BASO) dan limfosit (LYM). Hasil penelitian kami menunjukkan bahwa penundaan pemeriksaan dapat terdeteksi oleh scattergram Cell-Dyn Ruby khususnya channel WBC Differential setelah penundaan $12 \mathrm{jam}$, dan terlihat secara nyata setelah penundaan 24 jam. Saran penelitian ini adalah pemanfaatan scattergram untuk tindakan verifikasi kelayakan bahan pemeriksaan dan perlunya ada penelitian lanjutan untuk validasi dengan hapusan darah serta adanya komparasi dengan alat lain yang memiliki teknologi berbeda.

Kata kunci : Cell-Dyn Ruby, diff count, penundaan, scattergram

\section{PENDAHULUAN}

Hitung jenis leukosit atau dikenal juga dengan differential count (diff count) adalah pemeriksaan untuk menentukan jumlah jenis leukosit yang ditetapkan dalam persen (\%) maupun nilai absolut $(/ \mu \mathrm{L})$ (Nugraha and Badrawi, 2018). Selama beberapa dekade terakhir, pemeriksaan diff count dilakukan dengan penganalisis hematologi otomatis yang dikenal dengan hematology analyzer. Perkembangan teknologi yang pesat dalam laboratorim hematologi menawarkan pemeriksaan parameter leukosit yang semakin kompleks dan canggih seperti flaging, histogram serta scattergram (Keohane, Smith and Walenga, 2016).

Leukosit adalah kelompok heterogen dari sel berinti yang dapat ditemukan dalam sirkulasi darah. Leukosit diklasifikasikan menjadi neutrofil, eosinofil, basofil, limfosit, dan monosit. Penundaan pemeriksaan baik pada suhu ruang maupun suhu reprigerator $\pm 4^{\circ} \mathrm{C}$ dapat mempengaruhi hasil pemeriksaan diff count (Zini, 2014; Daves et al., 2015; Buoro et al., 2016). Dilaporkan bahwa penundaan pemeriksaan dapat mengubah morfologi leukosit pada sediaan apusan darah tepi. Beberapa neutrofil menunjukkan pembengkakan inti dan warna lebih homogen, hilangnya struktur lobus yang menjadi terpisah, sitoplasma kurang jelas, terjadi vakuolisasi serta hilangnya granula. Sel mononuklear juga mengalami perubahan morfologi yang serupa pada tingkat yang lebih rendah daripada neutrofil, yaitu vakuola dan lobulasi inti tidak teratur hingga disintegrasi inti (Zini, 2014). Permasalahannya adalah gambaran scattergram diff cout pada penundaan pemeriksaan belum pernah dilaporkan.

Cell-Dyn Ruby merupakan salah satu hematology analyzer 5-part differential yang diproduksi oleh Abbott Diagnostics Instrumentation (www.abbottdiagnostics.com).

Pemeriksaan diff count dilakukan dengan teknologi multiangle polarized scatter separation (MAPSS) yang didasarkan pada prinsip hamburan cahaya. Sebaran cahaya 0 derajat digunakan untuk penentuan volume sel, pengukuran sebaran cahaya ortogonal 90 derajat digunakan untuk penentuan lobularitas seluler, pengukuran sebaran sudut 7 derajat dihubungkan dengan kompleksitas seluler dan pengukuran sebaran cahaya depolarisasi 90 derajat digunakan untuk evaluasi granularitas seluler. Kombinasi dari empat pengukuran ini digunakan untuk membedakan dan mengukur lima subpopulasi leukosit utama yaitu neutrofil, limfosit, monosit, eosinofil, dan basofil dengan membentuk 2 jenis 
scattergram, yaitu WBC Differential dan NEU-EOS (neutrofil-eosinofil) seperti pada Gambar 1 (Keohane, Smith and Walenga, 2016).

Penundaan pemeriksaan pada pelayanan laboratorium sangat mungkin terjadi dan menjadi salah satu penyumbang kesalahan pada hasil pemeriksaan (Plebani, 2006). Penundaan pemeriksaan biasanya terjadi pada kondisi seperti lokasi pengambilan darah dengan laboratorium yang sangat jauh, terjadinya antrian pemeriksaan akibat jumlah pemeriksaan atau terbatasnya petugas laboratoium. Kondisi lain yang memungkinkan penundaan dalam waktu lama yaitu penyimpanan bahan pemeriksaan untuk keperluan konfirmasi jika terjadi komplain (Tang et al., 2019). Kondisi tersebut dapat mempengaruhi akurasi pemeriksaan, sehingga petugas laboratorium harus mampu mendeteksi perubahan tersebut salah satunya melalui scattergram pada hematology analyzer. Berdasarkan latar belakang tersebut dilakukan suatu penelitian dengan tujuan untuk mendapatkan gambaran scattergram diff count Cell-Dyn Ruby pada bahan pemeriksaan yang ditunda.

\section{METODE}

\section{Desain, tempat dan waktu}

Penelitian menggunakan desain Experimental Laboratory dengan rancangan one group pretest and posttest design. Penelitian dilakukan di Laboratorium Klinik Pramita Jemur Andayani, Kota Surabaya, Jawa Timur pada bulan Juli 2020. Penelitian ini telah disetujui Komisi Etik Penelitian Kesehatan Universitas Nahdlatul Ulama Surabaya dengan nomor 133/EC/KEPK/UNUSA/ 2020.

\section{Bahan dan alat}

Bahan yang digunakan dalam penelitian yaitu K2 EDTA sebagai antikoagulan. Alat yang digunakan dalam penelitian ini terdiri dari tabung pengumpul darah BD Vacutainer ${ }^{\circledR}$ (Becton, Dickinson and Company, United States) dan hematology analyzer CELL-DYN Ruby (Abbott, United States).

\section{Langkah-langkah penelitian}

Sebanyak $3 \mathrm{~mL}$ darah vena ditampung pada tabung Vacutainer, pengambilan darah dilakukan sesuai protokol standar flebotomi. Tabung yang sudah berisi darah dengan segera dilakukan pemeriksaan hematologi menggunakan hematology analyzer Cell-Dyn Ruby, hasil pemeriksaan dimasukkan sebagai kelompok kontrol (0 jam).

Selanjutnya bahan pemeriksaan disimpan pada suhu ruang dan dikontrol secara ketat agar tetap pada rentang 20 $25^{\circ} \mathrm{C}$. Setiap penundaan selama 6,12 dan 24 jam dari pengambilan darah, dilakukan pemeriksaan hematologi. Hasil penundaan pemeriksaan 6, 12 dan 24 jam dimasukkan sebagai kelompok perlakuan.

Pemeriksaan yang dianalisis meliputi scattergram WBC Differential dan scattergram NEU-EOS. Parameter leukosit digunakan untuk melengkapi informasi scattergram. Analisis dilakukan dengan menggunakan nilai absolut pemeriksaan bukan persentase. Karena nilai persentase dipengaruhi oleh jumlah jenis sel lainnya. Parameter leukosit yang digunakan meliputi white blood cell (WBC), neutrofil segmen (SEG), neutrofil batang (BAND), immature granulocytes (IG), monosit (MONO), eosinofil (EO), basofil (BASO) dan limfosit (LYM).

Pengolahan dan analisis data

Data disajikan dalam rerata, standar deviasi (SD) dan persen. Analisis statistik dilakukan dengan menggunakan SPSS versi 21 (IBM, United States).

Channel WBC Differential dan 
NEU-EOS dilakukan analisis dengan melakukan pengamatan perubahan pola pada scattergram.

Data hasil pemeriksaan dilakukan uji beda menggunakan Repeated Measures Anova, data yang tidak terdistribusi normal dan tidak homogen dilakukan menggunakan uji Friedeman. Hasil uji beda signifikan dilanjutkan dengan Pairwise comparisons. Derajat kemaknaan ( $p$ value) yang digunakan dalam penelitian ini yaitu $5 \%$.

\section{HASIL}

\section{Karakteristik sampel penelitian}

Sebanyak 30 spesimen darah vena dikumpulkan dari responden yang secara sukarela berpartisipasi dalam penelitian ini. Responden memiliki karakteristik usia rerata $22 \pm 1$ tahun, terdiri dari $27 \%$ pria dan $73 \%$ wanita.

Pengumpulan spesimen darah (flebotomi) dilakukan di lokasi yang sama dengan pemeriksaan diff count. Spesimen darah yang terkumpul dengan segera di bawa kelaboratorium dan dilakukan pemeriksaan menggunakan Cell-Dyn Ruby. Pemeriksaan ini di anggap pemeriksaan pada 0 jam dan digunakan sebagai kontrol pada penelitian.

Spesimen darah yang telah dilakukan pemeriksaan pada 0 jam, selanjutnya disimpan pada suhu ruang. Selama penelitian (24 jam), suhu ruangan terkontrol pada kisaran 24 $25^{\circ} \mathrm{C}$.

\section{Gambaran scattergram}

Pengamatan channel WBC differential (Gambar 2) menunjukan adanya perubahan scattergram yang nyata pada bahan pemeriksaan yang ditunda 24 jam pada suhu ruang. Perubahan terlihat pada peningkatan jumlah titik pada warna hitam dan merah muda, serta adanya pelebaran distribusi titik warna oranye.
Gambaran scattergram WBC differential pada penundaan selama 6 jam, secara keseluruhan (100\%) memiliki sebaran titik yang sama dengan kontrol. Penundaan selama 12 jam memperlihatkan adanya perubahan kecil pada scattergram WBC differential, sebanyak $43 \%$ ditemukan peningkatan jumlah titik pada warna hitam. Sebanyak 33\% ditemukan peningkatan jumlah titik pada warna merah muda. Sebanyak $77 \%$ ditemukan pelebaran distribusi titik warna oranye. Penundaan selama 24 memperlihatkan seluruh scattergram $W B C$ differential mengalami perubahan baik peningkatan jumlah titik pada warna hitam dan merah muda, serta pelebaran distribusi titik warna oranye. Uniknya kepadatan warna oranye menurun pada penundaan 24 jam.

Pengamatan scattergram channel NEU-ESO (Gambar 3) tidak begitu jelas, akan tetapi ditemukan adanya perubahan threshold. Penundaan selama 6 jam ditemukan sebanyak 3\%, penundaan 12 jam sebanyak $27 \%$ dan penundaan 24 jam sebanyak $63 \%$.

\section{Stabilitas parameter leukosit}

Berdasarkan uji statistik, terdapat perbedaan hasil pemeriksaan secara signifikan $(\mathrm{P}<0,01)$ pada seluruh parameter pemeriksaan leukosit (Tabel 1). Penundaan selama 6 jam secara signifikan memberikan perbedaan hasil pada IG. Penundaan selama 12 jam secara signifikan memberikan perbedaan hasil pada SEG, IG dan MONO. Penundaan selama 24 jam secara signifikan memberikan perbedaan hasil pada WBC, SEG, MONO, EO, BASO dan LYM.

Parameter BAND tidak dapat dilakukan uji statistik (NA), akan tetapi pada penundaan 12 dan 24 jam ditemukan adanya sel terhitung. Kasus terhitungnya BAND pada penundaan 12 jam ditemukan pada 1 bahan pemeriksaan, sedangkan penundaan 24 
jam ditemukan pada 9 bahan pemeriksaan.

\section{PEMBAHASAN}

Hematology analyzer adalah alat penghitung sel darah otomatis dan banyak parameter tambahan yang dapat memberikan lebih banyak informasi klinis. Secara garis besar hematology analyzer di kelompokan menjadi 3 bagian (3-part diff), 5 bagian (5-part diff) hingga 6 bagian (6-part diff) bahkan ada yang mengklaim mampu membedakan 7 bagian (7-part diff). Pembagian tersebut didasarkan kemampuan alam dalam membedakan jenis leukosit (Keohane, Smith and Walenga, 2016; Chhabra, 2018).

Analisis diff count pada hematology analyzer dilakukan dengan berbagai macam teknologi yang berbeda, seperti impedansi listrik (impedance), konduktivitas frekuensi radio, penghamburan cahaya (light scatter), penghamburan fluoresen (fluorescent scatter) dan sitokimia, dll (Chhabra, 2018). CELL-DYN Ruby didasarkan pada teknologi light scatter yang kemudian menjadi multiangle polarized scatter separation (MAPSS) sebagai produk paten dari Abbott Diagnostics Instrumentation. (Keohane, Smith and Walenga, 2016).

Penundaan pemeriksaan hematolgi menggunakan CELL-DYN Ruby menunjukkan adanya perubahan scattergram pada channel WBC Differential dan NEU-EOS. Perubahan ini meliputi peningkatan jumlah titik hitam dan merah muda, serta pelebaran distribusi titik warna oranye dan perubahan threshold.

Titik-titik hitam scatergram menunjukkan distribusi basofil, peningkatan jumlah titik menandakan adanya peningkatan jumlah basofil. Kondisi tersebut terbukti secara signifikan dari nilai rerata kadar basofil yang meningkat hingga 4,5 kali setelah ditunda selama 24 jam.

Titik-titik merah muda scatergram menunjukkan distribusi monosit. Kondisi ini terbukti dari nilai rerata kadar monosit yang mengalami peningkatan secara signifikan.

Titik-titik hitam scatergram menunjukkan distribusi IG, SEG dan BAND. Sel blast pada penelitian ini tidak dilakukan pengukuran. Penundaan pemeriksaan nilai rerata IG dapat berdampak peningkatan pada 6 dan 12 jam, tetapi tidak signifikan pada 24 jam. Nilai rerata SEG mengalami penurunan secara signifikan setelah 12 jam. Sedangkan BAND yang awalnya tidak sel tidak terhitung, teranalisis setelah penundaan 12 jam.

Parameter leukosit lainnya tidak terdeteksi pada scattergram, tetapi ditemukan adanya perubahan yang signifikan. EO mengalami penurunan setelah penundaan 24 jam dan pada LYM mengalami peningkatan setelah 24 jam.

Hasil tersebut tidak sejalan dengan penelitian yang dilakukan oleh Hedberg P. dan Letho T. (2009) yang menggunakan instrumen Cell-Dyn Ruby. Parameter pemeriksaan leukosit tidak ada perbedaan hingga 24 jam, kecuali EO yang mengalami penurunan secara signifikan setelah ditunda 24 jam (Hedberg and Lehto, 2009). Kemungkinan perbedaan terjadi akibat proses penuaan sel pada penelitian ini lebih cepat, mengingat penelitian di lakukan di beda negara yang memiliki karakter iklim berbeda.

Perhatian khusus tertuju pada parameter yang mengalami peningkatan seperti BAND, IG, MONO, BASO dan LYM. Khususnya BAND dan IG yang merupakan sel muda (imature) dari SEG, secara garis keturunan SEG tidak memungkinkan kembali menjadi sel imature (Keohane, Smith and Walenga, 
2016). Sesuai studi yang dilakukan Zini (2014), penundaan pemeriksaan dapat menyebabkan neutrofil mengalami kehilangan lobularitas, sitoplasma kurang jelas serta hilangnya granula. Sehingga titk oranye pada scattergram WBC Differential mengalami pergeseran yang menyebabkan berada pada treshold BAND dan IG.

Begitu pula dengan peningkatan MONO dan LYM, kedua sel tersebut memiliki morfologi yang serupa dengan sel imature neutrofil. Sehingga dicurigai peningkatannya disebabkan akibat perubahan dari morfologi SEG. Kenyataannya SEG, mengalami penurunan yang signifikan pada penelitian ini.

Zini juga melaporkan adanya pembentukan vakuola pada Neutrofil (SEG dan BAND), dalam jumlah sedikit pada MONO dan LYM (Zini, 2014). BASO merupakan leukosit yang jumlahnya sedikit dibandingkan jenis lainnya. Ciri khas sel ini adalah ukuran granulanya yang tidak teratur dan menutupi inti sel (Nugraha, 2017). Vakuolisasi tersebut ada kemungkinan memiliki komleksitas yang sama dengan granula pada BASO, sehingga dapat berdampak pada pembacaan hasil pemeriksaan BASO meningkat.

Kelemahan dalam penelitian ini yaitu tidak dilakukan pembuatan hapusan darah, sehingga berbagai macam perubahan yang terjadi pada leukosit tidak teramati secara morfologis dibawah mikroskop.

\section{KESIMPULAN}

Hasil penelitian kami menunjukkan bahwa penundaan pemeriksaan dapat terdeteksi oleh scattergram Cell-Dyn Ruby khususnya channel WBC Differential setelah penundaan 12 jam, dan terlihat secara nyata setelah penundaan 24 jam. Gambaran yang didapat berupa peningkatan jumlah titik pada warna hitam dan merah muda, serta adanya pelebaran distribusi titik warna oranye dengan kepadaatan warnya yang memudar.

\section{SARAN}

Saran praktis penelitian ini adalah pemanfaatan scattergram CellDyn Ruby khususnya channel WBC Differential untuk tindakan verifikasi kelayakan bahan pemeriksaan yang tertunda atau sudah disimpan lama. Sehingga dapat mencegah hasil pemeriksaan yang tidak akurat.

Saran untuk penelitian selanjutnya yaitu perlu dilakukan validasi dengan hapusan darah serta adanya komparasi dengan alat lain yang memiliki teknologi berbeda.

\section{UCAPAN TERIMA KASIH}

Laboratorium Klinik Pramita Jemur Andayani Kota Surabaya yang telah membantu memfasilitasi pemeriksaan laboratorium. Lembaga Penelitian dan Pengabdian Masyarakat Universitas Nahdlatul Ulama Surabaya yang telah memberi dukungan penelitian.

\section{DAFTAR PUSTAKA}

Buoro, S. et al. (2016) 'Assessment of blood sample stability for complete blood count using the Sysmex XN-9000 and Mindray BC-6800 analyzers', Revista Brasileira de Hematologia e Hemoterapia. Elsevier Editora Ltda, 38(3), pp. 225-239. doi: 10.1016/j.bjhh.2016.05.010.

Chhabra, G. (2018) 'Automated hematology analyzers: Recent trends and applications', Journal of Laboratory Physicians. Georg Thieme Verlag KG, 10(01), pp. 015-016. doi: 10.4103/jlp.jlp_124_17. 
Daves, M. et al. (2015) 'Sample stability for complete blood cell count using the Sysmex XN haematological analyser', Blood Transfusion. SIMTI Servizi Sri, 13(4), pp. 576-582. doi: 10.2450/2015.0007-15.

Hedberg, P. and Lehto, T. (2009) 'Aging stability of complete blood count and white blood cell differential parameters analyzed by Abbott CELL-DYN Sapphire hematology analyzer', International Journal of Laboratory Hematology. Int J Lab Hematol, 31(1), pp. 87-96. doi: $10.1111 / \mathrm{j} .1751-$ 553X.2007.01009.x.

Keohane, E. M., Smith, L. J. and Walenga, J. M. (2016) Rodaks's Hematology: Clinical Principles and Application. 5th edn. Missouri: Elsevier.

Nugraha, G. (2017) Panduan Pemeriksaan Laboratorium Hematologi Dasar. Ke-2. Jakarta: Trans Info Media.

Nugraha, G. and Badrawi, I. (2018)
Pedoman Teknik Pemeriksaan Laboratorium Klinik untuk Mahasiswa Teknologi Laboratorium Medik. Jakarta: Trans Info Media.

Plebani, M. (2006) 'Errors in clinical laboratories or errors in laboratory medicine?', in Clinical Chemistry and Laboratory Medicine, pp. 750-759. doi: 10.1515/CCLM.2006.123.

Tang, O. et al. (2019) 'Short-Term Stability of Hematologic Parameters in Frozen Whole Blood', The journal of applied laboratory medicine. NLM (Medline), 4(3), pp. 410-414. doi: 10.1373/jalm.2018.028357.

Zini, G. (2014) 'Stability of complete blood count parameters with storage: Toward defined specifications for different diagnostic applications', International Journal of Laboratory Hematology. Blackwell Publishing Ltd, pp. 111-113. doi: 10.1111/ijlh.12181. 

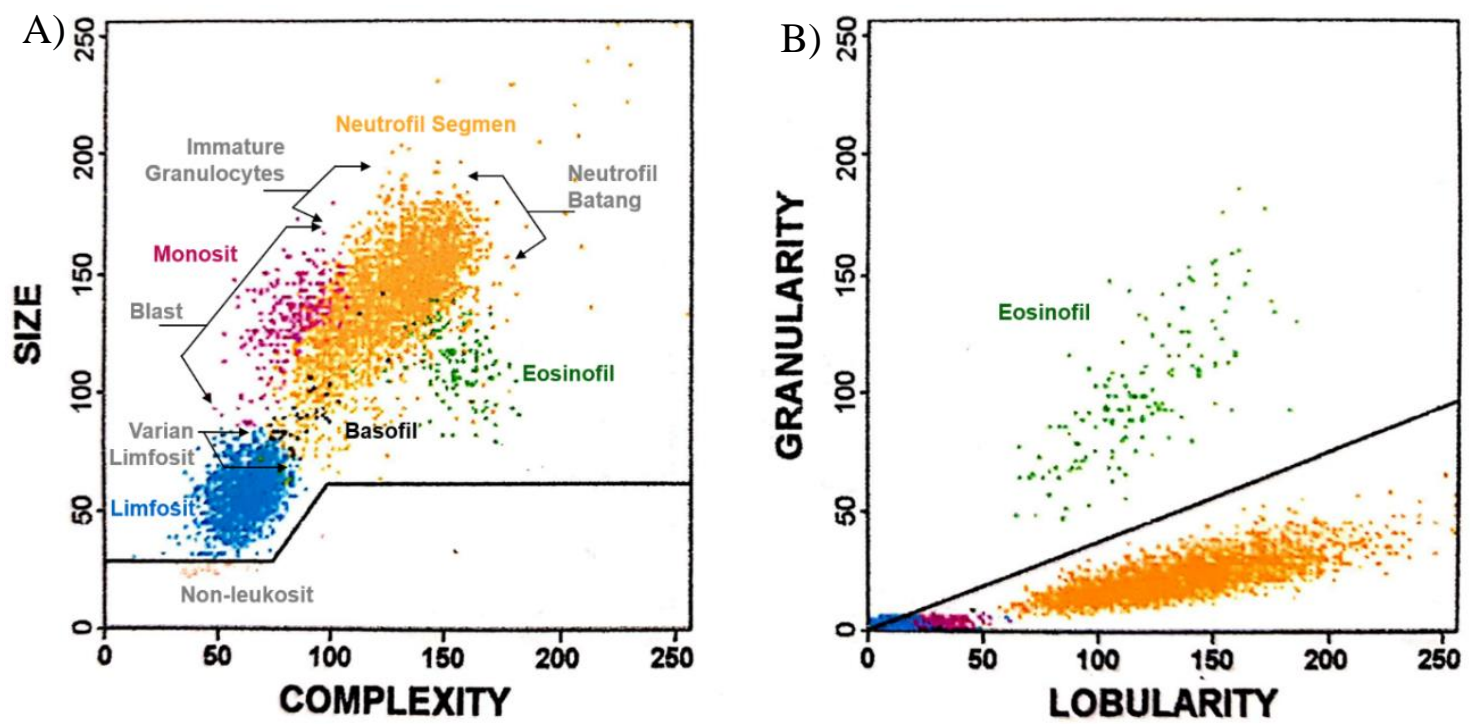

Gambar 1. Scattergram Cell-Dyn Ruby. A) Channel WBC Differential.

B) Channel NEU-EOS
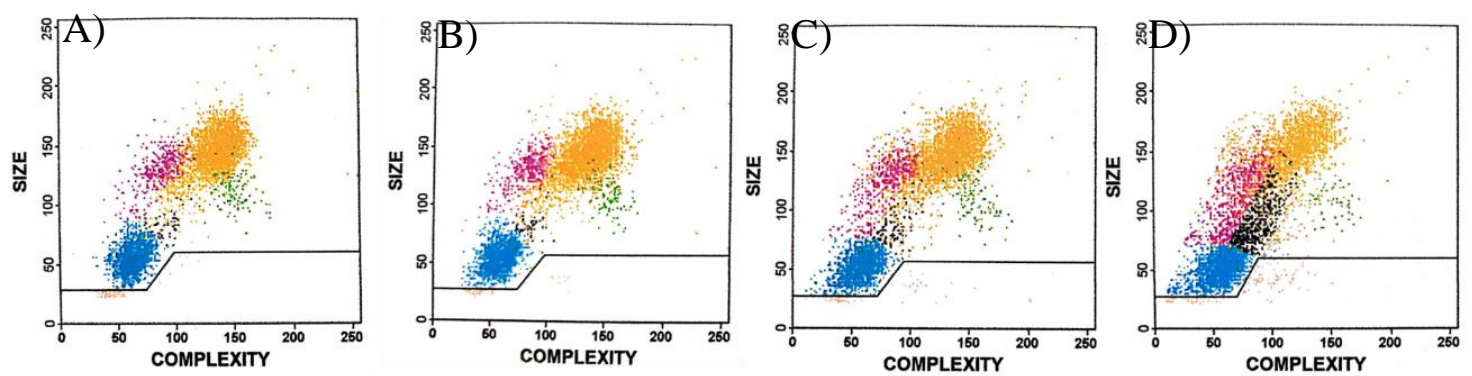

Gambar 2. Scattergram WBC differential. A) Penundaan 0 jam. B) Penundaan 6 jam. C) Penundaan 12 jam. D) Penundaan 24 jam.
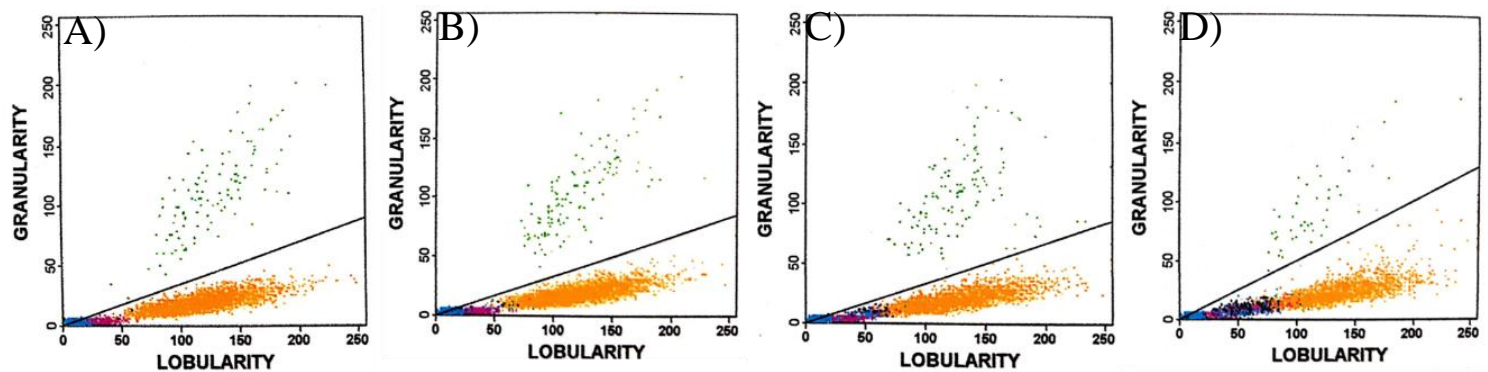

Gambar 3. Scattergram NEU-ESO. A) Penundaan 0 jam. B) Penundaan 6 jam. C) Penundaan 12 jam. D) Penundaan 24 jam. 
Tabel 1

Karakteristik Hasil Pemeriksaan Parameter Leukosit yang Ditunda pada Suhu Ruang

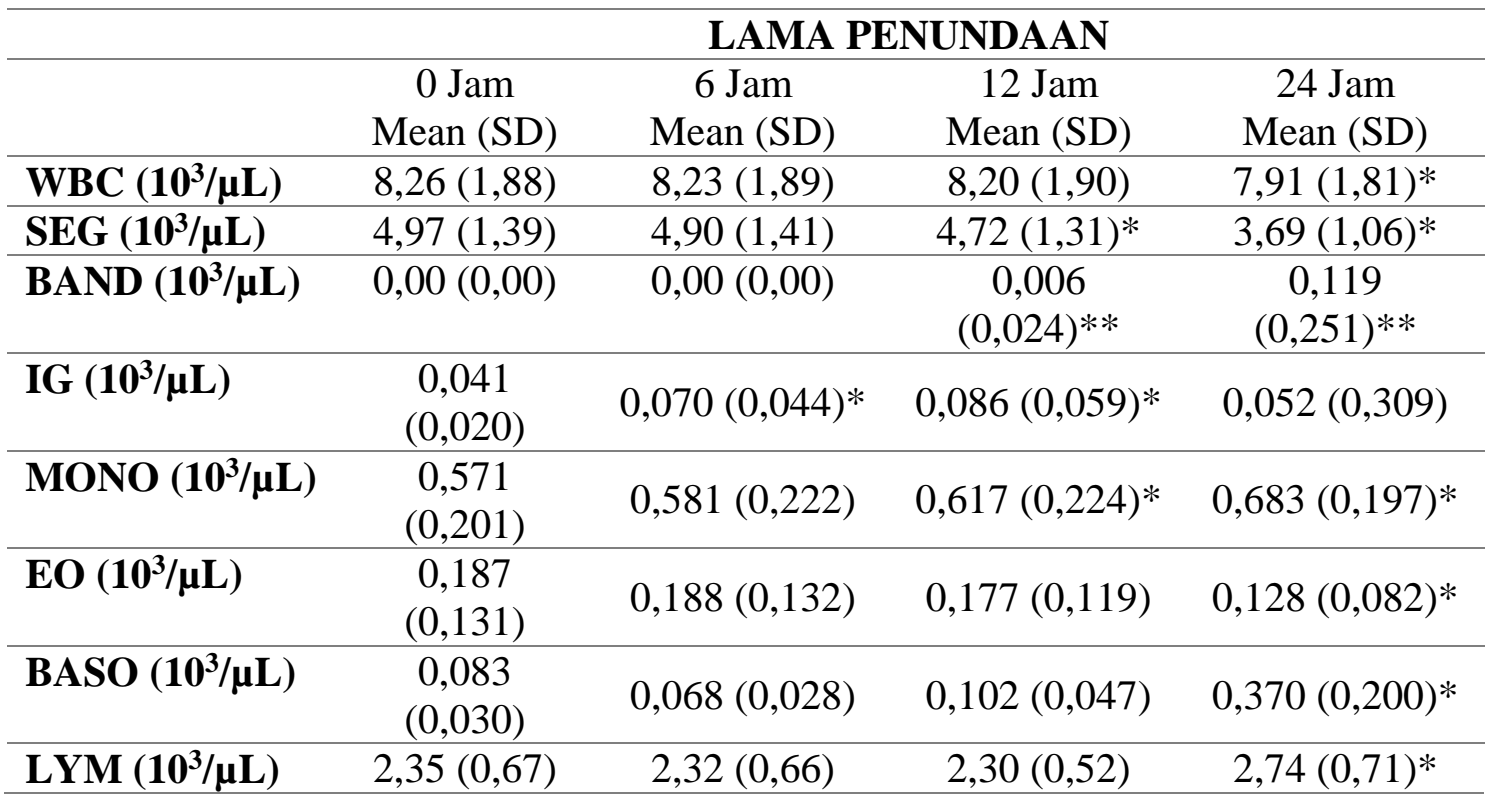

Keterangan:

*Nilai rerata parameter terdapat perbedaan sigifikat dengan kontrol secara statistik atau $\mathrm{P}<0,05$.

**NA (not available) pada uji statistik 